\title{
Type III Gastric Neuroendocrine Tumor - a Case Report
}

\author{
Teodora SPATARU', George PARIZA², Lucian NEGREANU ${ }^{1}$
}

\begin{abstract}
We present the case of a 71 year old female that was endoscopically diagnosed with type III neuroendocrine gastric tumor (NET). NETs are rare, slowly growing neoplasm originating in the neuroendocrine cells, that can occur anywhere in the body. Gastrointestinal forms account for more than a half of them. If type I and II gastric neuroendocrine tumors can be managed endoscopically, type III and IV have sugery as their main therapy. Because type III lessions have the greatest potential to generate metastasis, we did a CT scan on the patient and found distant metastasis located in the liver and also to the lymph nodes. Treatment options depend on the type of tumor, its location, signs and symptoms experienced by the patient, due to excess hormones produced by the tumor, and also if there is resectable metastatic disease or not. Altough our patient had a voluminous tumor, surgical resection was possible, followed by chemotherapy, with good evolution.
\end{abstract}

Keywords: neuroendocrine tumor, NET, endoscopy, digestive bleeding, gastric, polyp.

\section{Rezumat}

Va prezentăm cazul unei paciente de 71 de ani, diagnosticată endoscopic cu tumoră neuroendocrină gastrică tip III. Tumorile neuroendocrine reprezintă un tip rar de neoplasm cu originea în celulele neuroendocrine, cu o dezvoltare lentă și care pot să apară oriunde în organism. Mai mult de jumătate din aceste tumori apar la nivel gastrointestinal. Dacă tipul I și II pot fi abordate endoscopic, pentru tipul III și IV de elecție este intervenția chirurgicală. Având în vedere rata crescută de incidență pentru metastaze ce apare la tumorile de tip III, pacienta a fost evaluată imagistic, imaginile de CT arătând metastaze la nivel hepatic și al ganglionilor limfatici. Opțiunile de tratament depind de tipul tumorii, localizarea acestora, semnele și simptomele pacientului date de excesul de hormoni produs de tumoră și de asemenea de posibilitatea rezecției metastazelor. Deși tumora descoperită la pacienta noastră era voluminoasă, a fost posibilă rezecția chirurgicală, care a fost urmată de chimioterapie, cu o evoluție favorabilă.

Cuvinte cheie: tumoră neurendocrină, NET, endoscopie, hemoragie digestivă, gastric, polip.

\section{INTRODUCTION}

Neuroendocrine tumors (NETs) are rare, slowly growing neoplasms originating in the neuroendocrine cells. They can occur anywhere in the body, but most commonly occur in the lungs, appendix, small intestine, rectum and pancreas ${ }^{1}$.
Gastrointestinal tract NETs account for $67 \%$ of NETs, the small bowel (especially the ileum) being the most frequent primary site, with an incidence of $42 \%$ within this group. Also, NETs account for $37 \%$ of all small bowel cancers ${ }^{2}$. Their clinical behavior can range from benign to malignant ${ }^{3}$.

\footnotetext{
1 Department of Gastroenterology, Emergency University Hospital, "Carol Davila" University of Medicine and Pharmacy, Bucharest, Romania

${ }_{2} 3^{\text {rd }}$ Department of Surgery, Emergency University Hospital, "Carol Davila" University of Medicine and Pharmacy, Bucharest, Romania
}

Corresponding author. Lucian NEGREANU, Department of Gastroenterology, Emergency University Hospital, „Carol Davila” University of Medicine and Pharmacy, Bucharest, Romania.

E-mail: negreanu_99@yahoo.com 


\section{CASE PRESENTATION}

A 71 year old female presented with intense fatigue, weight loss and several episodes of melena. On physical exam, the abdomen was soft, non-distended, and painful in the epigastric area.

Routine test revealed severe hypochromic, microcytic anemia with a hemoglobin of $6.1 \mathrm{~g} / \mathrm{dL}$ (NR: 10.9$14.3 \mathrm{~g} / \mathrm{dL}$ ) and a blood iron level of $5 \mathrm{ug} / \mathrm{dL}$ (NR: 50$170 \mathrm{ug} / \mathrm{dL}$ ), ferritin level of $6.3 \mathrm{ng} / \mathrm{mL}$ (NR: 15-150 $\mathrm{ng} / \mathrm{mL}$ ), a blood urea nitrogen level of $54 \mathrm{mg} / \mathrm{dL}$ (NR: $19.26-49.22 \mathrm{mg} / \mathrm{dL})$ and an elevated $\mathrm{C}$ reactive protein $5.3 \mathrm{mg} / \mathrm{dL}$ (NR: $0-1 \mathrm{mg} / \mathrm{dL}$ ).

An esophagogastroduodenoscopy was performed using the Sonoscape 550 endoscope and the 4 LED processor, showing a polypoid ulcerated lesion with a large implantation base - approximately $7 \mathrm{~cm}$ in diameter, located medio-gastric on the great curvature. Multiple infra-centimetric polyps were spotted in the gastric corpus and the gastric mucosa appeared pale with visible vascularization of the submucosa. Multiple biopsies were taken (Figure 1).

A CT scan for evaluation was performed and showed a voluminous gastric tumor with distant metastasis located in the liver (segments 5 and 7) and also to the lymph nodes.

The patient was referred for surgery and underwent a subtotal gastrectomy with a gastro-entero-anastomosis, including a peri-gastric lymph node dissection (Figures 2 and 3 ).

The pathology exam revealed a polypoid mass with an $8 \mathrm{~cm}$ diameter, with a histological aspect of a type III neuroendocrine tumor, grade 2 according to the World Health Organization classification, the mitotic

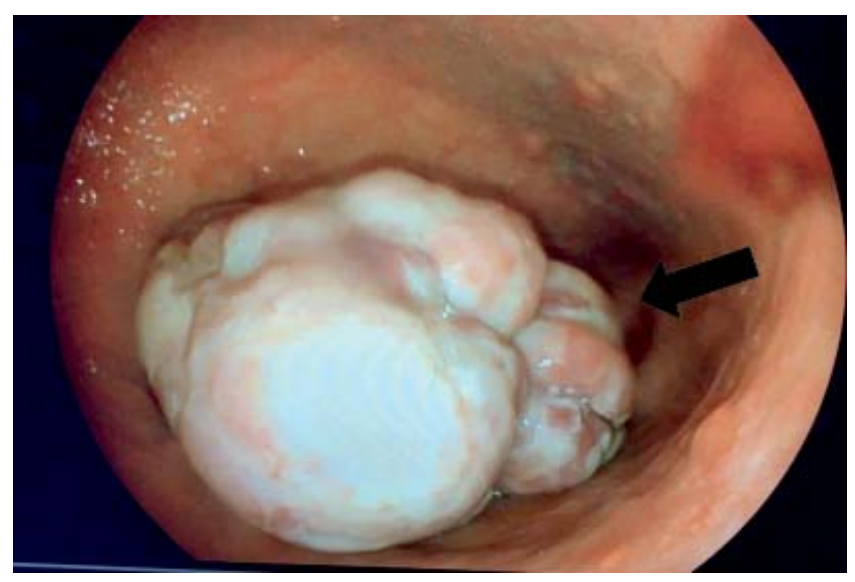

Figure 1. Intraprocedural image of a voluminous polypoid ulcerated lesion with a large implantation base and multiple infracentimetric polyps.

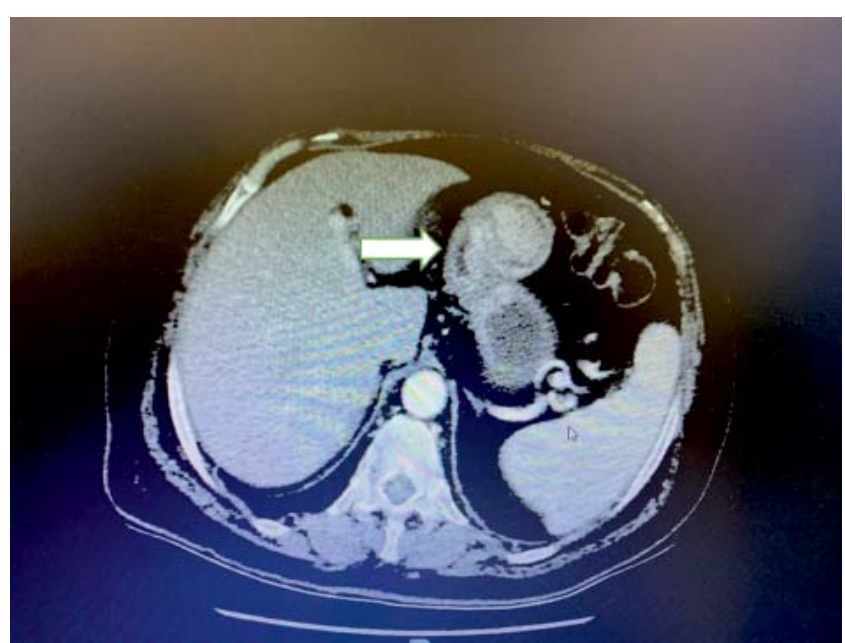

Figure 2. CT scan image showing a voluminous iodophile vegetant gastric tumor.

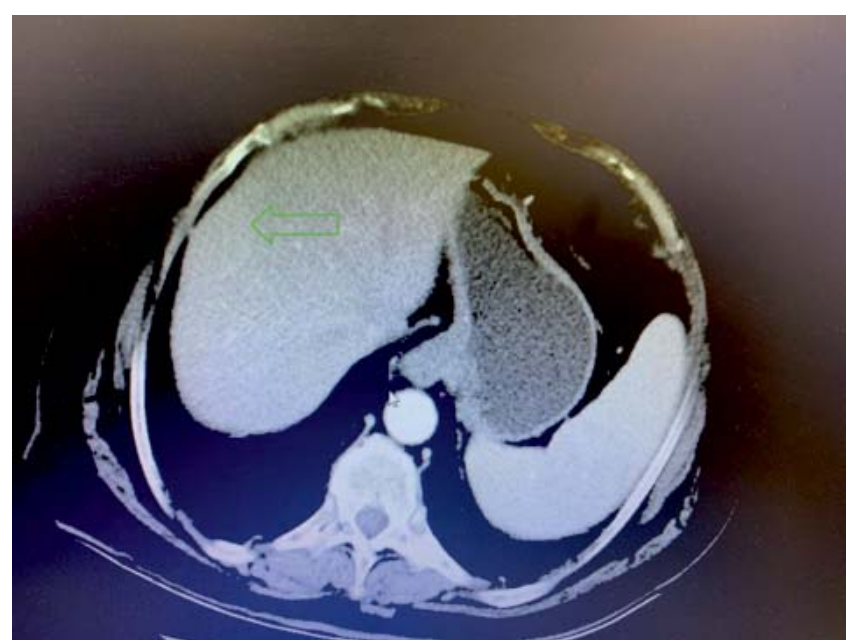

Figure 3. CT scan image of a subcapsular liver metastasis.

rate being 7 per 2 power fields. Out of 7 lymph nodes examined, 4 presented tumoral invasion. According to AJCC edition 8- it is a pT1 N1 stage.

The patient had an uneventful postoperative course.

\section{DISCUSSION}

Based on morphological characteristics there are four types of neuroendocrine tumors.

The type I lesions correspond to the majority of gastrointestinal NETs found in the stomach (70-80\%) and are associated with autoimmune chronic atrophic gastritis. Diagnosis of type I is made by upper gastrointestinal endoscopy with biopsy that reveals pale, yellowish and transparent blood vessels of the antral mucosa. The 
Type III Gastric Neuroendocrine Tumor - a Case Report

neuroendocrine tumors are visualized as small, reddish polyps and often being multiple, with neuroendocrine cell hyperplasia on the histological examination. Anti-parietal cell and anti-intrinsic factor antibodies may also be present, and the gastric acidity dosage reveals high $\mathrm{pH}(\mathrm{pH}>7)^{4,5}$.

Type II lesions are caused by gastrinomas. Similarly to type I, they are usually benign with a low risk of malignancy. Often they are associated with Zollinger Ellison syndrome and in most cases, the patient has multiple endocrine neoplasia type $\mathrm{I}^{6}$. Gastric biopsy reveals normal or hypertrophic gastric mucosa, associated with hypergastrinemia and hyperchlorhydria ${ }^{7}$. After confirming the diagnosis, it is important to localize the gastrinoma and to remove it surgically, if possible ${ }^{8}$.

Type III lesions are sporadic lesions with the greatest potential to generate metastasis. Generally, the lesion is unique, larger than $1 \mathrm{~cm}$ and with normal gastrin levels. The largest type III mass described measures 10/7/7 $\mathrm{cm}$, located adjacent to the gastroesophageal junction, in the gastric wall ${ }^{9}$. Diagnosis is made by upper gastrointestinal endoscopy with biopsy. Rarely, the carcinoid syndrome can be the initial clinical manifestation ${ }^{10}$.

Type IV consists of multiple small lesions, histology revealing hypertrophy and hyperplasia of parietal cells associated with achlorhydria and hypergastrinemia ${ }^{11}$.

Most g-NETs are found on endoscopic examinations and because type I and II commonly present as polypoid lesions, they are often amenable to endoscopic resection ${ }^{12}$. For type III and IV gNETs surgical gastric resection is recommended, due to their behavior that is very similar to gastric adenocarcinomas, with a high incidence of invasion beyond the submucosa and distant metastasis on presentation $(50-100 \%)^{13}$.

Accurate tumor imaging is essential to planning the approach of management if patients with NETs. Surgical and endoscopic resection represents the only curative treatment methods. When the tumor is unresec- table imaging studies are essential in planning therapy and evaluating treatment response and the possible need for new approaches ${ }^{14}$. CT scan of the abdomen is recommended for type I and II gNETs larger than $2 \mathrm{~cm}$ and for all type III lesions. MRI of the abdomen, octreotide scintigraphy and PET-CT may be useful in specific cases ${ }^{15}$.

The treatment options depend on the type of tumor, its location and whether the patient is experiencing signs and symptoms of excess hormones produced by the tumor.

In general, treatment options might include chemotherapy, targeted drug therapy, peptide receptor radionuclide therapy (PRRT), medications to control excess hormones and radiation therapy, besides surgery ${ }^{1}$. If there is resectable metastatic disease, it should also be treated. For unresectable liver disease, local therapies such as arterial embolization or radio-ablation have a success rate of $50 \%{ }^{16}$. For the carcinoid syndrome, symptom control is achieved using somatostatin analogs (octreotide or lanreotide) and low doses interferon alfa for refractory cases ${ }^{17}$.

\section{CONCLUSION}

Gastric NETs include 4 different subtypes that have distinct pathogenesis and management, and need to be correctly diagnosed in order to be able to prescribe the correct course of treatment. Although our patient had a voluminous tumor, surgical resection was possible and chemotherapy was started with good evolution.

Compliance with ethics requirements: The authors declare no conflict of interest regarding this article. The authors declare that all the procedures and experiments of this study respect the ethical standards in the Helsinki Declaration of 1975, as revised in 2008(5), as well as the national law. Informed consent was obtained from all the patients included in the study. 


\section{References}

1. Neuroendocrine tumors: Diagnosis and treatment. Mayoclinic. org. https://www.mayoclinic.org/diseases-conditions/neuroen docrine-tumors/symptoms-causes/syc-20354132. Accessed November 16, 2020

2. Bilimoria $K Y$, Bentrem DJ, Wayne JD, Ko CY, Bennett $C L$, et al. (2009) Small bowel cancer in the United States: changes in epidemiology, treatment, and survival over the last 20 years. Ann Surg 249: 63-71.

3. E.D. Williams, M. SandlerThe classification of carcinoid tumors. Lancet, 1 (1963), pp. 238-239

4. Gladdy RA, Strong VE, Coit D. Defining surgical indications for type I gastric carcinoid tumor. Ann Surg Oncol. 2009; 16(11): 3154-3160.

5. Modlin IM, Kidd M, Latich I, Zikusoka MN, Shapiro MD. Current status of gastrointestinal carcinoids. Gastroenterology 2005;128(6):1717-1751

6. M. Schindl, K. Kaserer, B. NiederleTreatment of gastric neuroendocrine tumors: the necessity of a type-adapted treatment. Arch. Surg., 136 (2001), pp. 49-54

7. Pritchard DM. Zollinger-Ellison syndrome still a diagnostic challenge in the 21 st century? Gastroenterology. 2011;140(5):13801383.

8. Stabile BE, Morrow DJ, Passaro E., Jr The gastrinoma triangle operative implications. Am J Surg. 1984;147(1):25-31

9. S. La Rosa, A. Vanoli. Gastric neuroendocrine neoplasms and related precursor lesions. J. Clin. Pathol., 67 (2014), pp. 938948

10. Gastric neuroendocrine tumor: review and update. Ncbi.nlm.nih. org. https://www.ncbi.nlm.nih.gov/pmc/articles/PMC55437 97/. Accessed November 16,2020 .
11. Ooi A, Ota M, Katsuda S, Nakanishi I, Sugawara H, Takahashi I. An unusual case of multiple gastric carcinoids associated with diffuse endocrine cell hyperplasia and parietal cell hypertrophy. Endocr Pathol.

12. F.G. Delle, D.J. Kwekkeboom, C.E. Van, G. Rindi, B. Kos-Ku$\mathrm{dla}$, U. Knigge, et al.ENETS Consensus guidelines for the management of patients with gastroduodenal neoplasm. Neuroendocrinology, 95 (2012), pp. 74-87

13. R. Basuroy, R. Srirajaskanthan, A. Prachalias, A. Quaglia, J.K. Ramage Review article: the investigation and management of gastric neuroendocrine tumours. Aliment. Pharmacol. Ther., 39 (2014), pp. 1071-1084

14. Classification, clinicpathologic features and treatment of gastric neuroendocrine tumors. Ncbi.nlm.nih.gov. https://www. ncbi.nlm.nih.gov/pmc/articles/PMC5195891/.Accesed Novem ber 16, 2020.

15. Sundin A, Vullierme MP, Kaltsas G, Plöckinger U. Mallorca Consensus Conference participants.European Neuroendocrine Tumor Society ENETS Consensus Guidelines for the Standards of Care in Neuroendocrine Tumors radiological examinations. Neuroendocrinology. 2009;90(2):167-183.

16. Gupta S, Johnson MM, Murthy R. Hepatic arterial embolization and chemoembolization for the treatment of patients with metastatic neuroendocrine tumors variables affecting response rates and survival. Cancer. 2005;104(8):1590-1602.

17. Öberg K, Knigge U, Kwekkeboom D, Perren A. ESMO Guidelines Working Group Neuroendocrine gastro-entero-pancreatic tumors ESMO Clinical Practice Guidelines for diagnosis, treatment and follow-up. Ann Oncol. 2012;23(7):vii124-vii130. 